Boston University School of Law Scholarly Commons at Boston University School of Law

Faculty Scholarship

2014

\title{
The Fair Use Doctrine: Markets, Market Failure and Rights of Use
}

Wendy J. Gordon

Boston University School of Law

Follow this and additional works at: https://scholarship.law.bu.edu/faculty_scholarship

Part of the Intellectual Property Law Commons, and the Law and Economics Commons

\section{Recommended Citation}

Wendy J. Gordon, The Fair Use Doctrine: Markets, Market Failure and Rights of Use, Handbook on the Economics of Copyright: A Guide for Students and Teachers 77 (2014).

Available at: https://scholarship.law.bu.edu/faculty_scholarship/47 


\title{
4. The fair use doctrine: markets, market failure and rights of use ${ }^{1}$
}

\author{
Wendy J. Gordon
}

Markets are most acceptable when they serve efficiency and other goals. It is only under transaction-costless conditions of perfect knowledge, flawless and cost-free enforcement, full monetization, and instantaneous ability to organize and negotiate, that markets are guaranteed to generate efficient outcomes. And even then, markets could fall short as social tools, because goals other than allocative efficiency may fail to be met. ${ }^{2}$

However, neither the real-world inaccessibility of 'perfect' market conditions nor the importance of non-monetizable social goals requires us to jettison the use of markets. To decide if markets should be used, they need to be compared with their institutional alternatives, and all institutions are imperfect. In addition, there are ways to improve markets' functioning.

One device for improving their functioning is to create exceptions (in appropriate circumstances) to the property rules on which the troublesome markets rest. A substantial economic literature discusses the nature that these exceptions can take, in particular, the comparative merits of rules versus standards. ${ }^{3}$ Rules are hard-edged and definite, easily known in advance. Standards are open-textured, their applicability decided upon as cases arise, and their results harder to predict.

Copyright can be seen as a primarily rule-based exception to the usual rules of tangible-property ownership. Ordinarily, a property owner can do virtually anything non-harmful that he or she wants with her goods. However, because some tangible personalty (such as computers, video recorders, broadcast studios) can copy and perform works of authorship created by third parties, the usual liberty to use one's physical property would generate significant positive externalities; accordingly, copyright law limits those liberties, hoping thereby to direct some of the revenues to incentivizing the works' creators. Most of the copyright rules are fairly sharp-edged: for example, in the US, the purchaser of a lawfully made copy can resell it without liability or permission, but the purchaser of an unlawfully made copy has no such liberty; public performances must be licensed, but private performances need not be. Out of these rules, markets in the intangible known as 'works of authorship' evolve. 
These markets, too, cannot accomplish all a society desires. Therefore, in turn, copyright too has exceptions and limits. The 'fair use doctrine' discussed further herein can be seen as a standards-based exception to the intangible-property markets that copyright law creates.

But first some background is in order. This chapter sketches the economic background, describes fair use as a legal doctrine, and then returns to further flesh out the economic arguments.

\section{BACKGROUND: FROM TANGIBLE CHATTELS TO INTANGIBLE WORKS OF AUTHORSHIP}

According to the consensus view, 'property' connotes the joinder of at least three sets of entitlements: a right or rights of exclusion over a resource, a power or powers to alienate the resource, and a broad set of liberties to use the resource. However, one particular subset of 'liberties to use' is likely not to be employed most valuably if left with a physical-property owner. That subset is the liberty to employ one's physical property to duplicate, adapt, and otherwise use the creative patterns originated by others. Those creative patterns - what American law terms, 'works of authorship' - are the subject matter of copyright.

The difficulty with leaving a full liberty of use with the physical-property owner of a manuscript or a piece of sheet music lies in part with a 'public goods' characteristic that works of authorship have: the patterns of words or music that works of authorship 4 contain are inexhaustible and sharable, so that without a special legal regime it would be difficult to exclude non-payors from use. For works of authorship, anyone who has access to even a single physical copy can physically multiply it an indefinitely high number of times. Without copyright, creators of valuable manuscripts or music would find it difficult to distinguish between users who would pay a great deal for access to the created work (such as publishers and radio stations) and users who would pay little (users such as readers and listeners).

A concern arises that if producers of works of authorship had no ability to appropriate a significant amount of the value generated, production of such works would likely be under-incentivized. Copyright law provides a mode of appropriation by creating a particular default scheme to surround the physical copies: ownership of the physical copies does not carry with it the power to duplicate the copies or publicly perform them for profit. A person or corporate entity that wants to reproduce or publicly perform a
work of authorship must generally negotiate with the copyright owner and pay to lift the default prohibition.

It's often said that in cases of doubt about where the highest-valued 
use would lie, the law should (following Coase, 1960, and Calabresi, 1961) place property rights where they can most easily be traded to higher-valued users if the initial allocation has erred. Placing an unlimited liberty to copy and perform with the public is a grant of entitlement that couldn't easily be reversed. ${ }^{5}$ It would be hard - nearly impossible in most cases - for consumers to organize and find ways to persuade their favorite authors to produce desired works. By contrast, centralizing control by placing an exclusive right over copying and performing in one entity allows for easier reversibility. An exclusive right so placed can easily be reallocated by the 'copyright owner' (the author (or her employer or assignee)) selling licenses or assignments to users who place a higher value on the ability to employ the work.

This set of exclusive rights is limited to expression, and excludes ideas. ${ }^{6}$ A stable historical consensus holds that ideas within creative works are most valuably placed in the public's hands, even if once placed in such an open class they become effectively inalienable. By definition, an 'idea' is something so general that a multitude of widely varying expressions can give it form, and the law permits no one author to lock up such fertile seed, so that the purchaser of a book is free to make whatever use of the ideas he or she pleases. But that liberty does not extend to copying the selection, structure, and sequencing of elements that constitutes copyrightable expression.

When copyright was young, it might have been asked whether the prohibition-on-copying-expression and the prohibition-on-publicperformance fitted usual notions of numerus clausus; that is, one might have wondered whether limiting the usual liberties possessed by the owner of a tangible chattel is something that the public could understand and easily deal with. ('Numerus clausus' is a concept for limiting the shapes property rights should take in order to facilitate easy comprehension of their nature and thus facilitate trade. $)^{7}$ But, in the twenty-first century, most westerners are accustomed to the notion that they cannot use their computers, their sheet music, their guitars, their radio stations, books, DVDs, or photocopy machines to make unlimited public performances or copies. ${ }^{8}$ Physical property rights have been curtailed for the purpose of partly solving the problem of how to incentivize the creation of works of authorship.

Because copyright is enacted, ownership of books or musical scores, guitars, photocopy machines or broadcasting towers, does not carry with it as wide a set of liberties-to-copy-and-perform as owners of the physical objects would have had without copyright. Most of those owners would have usually been ill-placed to exploit such liberties commercially. After the coming of copyright, the chattel owner who has commercial capacity can usually obtain such liberties, by paying money. The liberties have been 
monetized in a way that they could not have been, had the full liberty of nonharmful use been allocated to the physical property owner. So copyright solves a market-failure problem that afflicted physical property. It creates a new kind of property - exclusive rights over copying and performing - that are transferable and waivable.

So copyright markets evolve. However, copyright itself creates a marketplace subject to failures. Sometimes potential buyers and sellers cannot contact each other; sometimes the pockets of potential buyers lack the money that would represent the productive value that the buyers could make of the authored work; sometimes potential sellers want compensation for monopoly power or mere pecuniary loss in a way that does not reflect public value; some sellers will not share their works at any price; sometimes societies have values such as free speech that should not be monetized; and some uses of works do have their highest value in the hands of the public, and sometimes requiring purchase of those liberties (for example, putting a price on free speech) would undermine important democratic institutions.

To these phenomena, the market of copyright-purchase is ill-adapted, but alternative solutions emerge. Some are sharply bordered rule-shaped solutions, like the hard lines that copyright law draws between private and public performance. ${ }^{9}$ (Only the latter is placed within the copyright owner's control.) It is fairly clear that giving authors the right to control private performance would be more costly than beneficial.) In addition to the sharp-lined exemptions, US law also recognizes open-textured standards, most notably the doctrine called fair use. A public performance or other use that does not fit within a specific exemption may nevertheless be free of liability if in the context the court decides the defendant's use is 'fair'.

\section{FAIR USE IN THE LAW}

The fair use doctrine allows some users of copyrighted works to proceed freely, despite the presence of what would seem to literally violate the copyright law. Found primarily in the US federal copyright law, the free-form doctrine of fair use unites a host of what otherwise might be discrete justifications and excuses under a generalized rubric of fairness. Economics helps us to understand the doctrine's many faces.

This section will discuss, first, the origins and functions of fair use; second, its current statutory instantiation in the US; third, the doctrine's relation to human rights concerns, including what the US Constitution calls 'the freedom of speech;' and fourth, the existence of possible tensions
between fair use as a national doctrine, and obligations under international treaties. The chapter then returns to focus on economics. 


\section{Origins and Functions of Fair Use in the Law}

When the US government first adopted a copyright statute in 1790, the statute was narrowly drawn to cover only three narrow rights: a copyright owner had the exclusive right to 'print, reprint, and vend'. These were the actions that, if done without consent of the copyright owner, could most dangerously erode the copyright owner's market. By contrast, anyone could lawfully make a 'fair abridgement', that reached a different audience or served a different purpose from the original book being abridged, without gaining the consent of the original copyright owner or paying him or her. For much of US history, courts usually viewed creative adaptations of copyrighted works as non-infringing.

Over time, the US Congress gave copyright owners additional exclusive rights, such as the exclusive right to do or authorize translations, abridgements and dramatizations of their work. In the 1976 Copyright Act, these rights were generalized as an exclusive right to control 'derivative works'. ${ }^{10}$ A derivative work is a work that creatively uses another work, much as a movie uses a novel from which its plot derives. Because Congress came to grant copyright owners the right to control creative uses, one might think that defendants can no longer shield themselves from liability by showing the creativity of their efforts; creative adaptations (when done without consent) would now seem as likely to infringe a copyrighted work as would the making of exact, substitutionary reproductions.

But judges understood that too literal an application of copyright law particularly in its expanded form - could 'stifle the very creativity' that copyright law was 'designed to foster'. Some of the old freedom for creative uses persisted in unsystematized judicial grants of liberty. A reviewer who quoted liberally from a copyrighted volume in order to criticize the book would likely be shielded from liability, as would many uses of copyrighted works by educators, newspapers, and researchers. The courts drew on the language of the old 'fair abridgment' cases (even though those cases were decided in a far different statutory framework) to grant free use to some of these defendants. 'Fair use' was the new label given.

Not everyone is a fan of the fair use doctrine. An opponent of fair use might point out that, in ideal circumstances, the broad right to control 'derivative works' can be enforced without imposing a stifling effect. For example, if a creative defendant were a commercial movie company, well able to negotiate a license and to pay licensing fees out of the movie's profits, the copyright owner's new right to control derivative works would discourage no one. Both the author of the book being licensed and the movie company paying the license fees would have incentives to produce, 


\section{Handbook on the economics of copyright}

and keep on producing, creative work. So, the opponent might conclude, there is no need for the fair use doctrine.

And indeed, the fair use doctrine might not have evolved into its current broad form if users of copyrighted works could always and easily have earned enough profit from their uses to afford hiring lawyers, negotiating licenses, and paying license fees. But it was clear to the judges that in too many instances, enforcing the copyright law would result not in licenses, but merely in stifling the defendant's proposed use. And even in some cases where licensing was physically possible, it was socially undesirable: for example, forcing critics to obtain consent from publishers whose books were being reviewed would likely taint the objectivity of the reviews so produced.

Fair use extended to some noncreative, exact copying as well. Photocopying for classroom use was recognized to have some claim to fair use treatment, for example. Admittedly, at one point in time a prestigious US Court held that fair use could not extend to exact copies that served the same purpose as the original. But the US Supreme Court reversed that decision, holding that the fair use doctrine could shield the makers of exact copies - in that case, it shielded television viewers who in their homes made VCR copies of broadcast copyrighted movies and programs for the purpose of watching the shows at a later time. ${ }^{11}$ A particularly plausible justification for the Court's decision to allow this home copying is that there seems to have been no practicable market through which home users could have purchased licenses to copy. ${ }^{12}$ Now that the internet and cable TV have reduced transaction costs, some commentators argue that fair use needs to shrink. ${ }^{13}$

\section{US Statute}

Although fair use began in the courts and continues to be a product of judicial evolution, Congress saw fit to ratify the judicial practice in America's 1976 Copyright Act. The relevant section provides that:

107. Notwithstanding the provisions of sections 106 [granting the basic set of rights in copyright] and 106A [granting moral rights in some works of visual art], the fair use of a copyrighted work, including such use by reproduction in copies or phonorecords or by any other means specified by that section, for purposes such as criticism, comment, news reporting, teaching (including multiple copies for classroom use), scholarship, or research, is not an infringement of copyright. In determining whether the use made of a work in any particular case is a fair use the factors to be considered shall include-

(1) the purpose and character of the use, including whether such use is of a commercial nature or is for nonprofit educational purposes;

(2) the nature of the copyrighted work;

(3) he amount and substantiality of the portion used in relation to the copyrighted work as a whole; and 
(4) the effect of the use upon the potential market for or value of the copyrighted work.

The fact that a work is unpublished shall not itself bar a finding of fair use if such finding is made upon consideration of all the above factors'. ${ }^{14}$

The legislative history clearly states that the statute is not meant to freeze the further judicial evolution of the doctrine.

\section{Flexible v. Hard-Edged Exceptions to Exclusive Rights}

In addition to this flexible doctrine, US Copyright law, like all copyright laws, contains a host of more specific and hard-edged exceptions and privileges. For example, specific provisions clarify that it does not violate copyright to stand on a public street and photograph the outside of a copyrighted building, or to copy the singing style of a famous band in your own band's playing and singing, or (under certain circumstances) to publicly perform non-dramatic musical works in the course of doing a charity benefit. Much debate surrounds the question of whether detailed exceptions like this suffice, or whether in addition a flexible doctrine like fair use should be adopted by countries which lack it. Given the way that rapid technological and social change can make it difficult to enact a rule to meet each new challenge, fair use might be important, in particular to safeguard the human rights of free expression and the public's use of its cultural heritage. Contrariwise, some observers wonder whether a country that has fair use should abolish it in favor of an expanded list of specifically sheltered uses. ${ }^{15}$

\section{International and Constitutional Dimension}

In addition, some observers argue that the United States must abolish or constrain the fair use doctrine in order to comply with its treaty obligations. ${ }^{16}$ The United States, like most developed nations, has signed both the Berne Convention and TRIPS. Berne provides (in a provision substantially duplicated in TRIPS) that:

It shall be a matter for legislation in the countries of the Union to permit the reproduction of such works in certain special cases, provided that such reproduction does not conflict with a normal exploitation of the work and does not unreasonably prejudice the legitimate interests of the author. (Emphasis added)

To determine the unresolved question of whether fair use and Berne are inconsistent, a number of issues remain to be answered, such as how narrowly and specifically the 'special cases' need to be described in the 
domestic legislation. The fair use doctrine in its generality allows judges to tailor cases to specific equities in a way a list of hard-edged exceptions would not permit.

In the United States, fair use has a Constitutional dimension. The US Constitution in its first amendment guarantees a 'freedom of speech' that expresses itself in part through the fair use doctrine. When the Supreme Court of the US upheld a recent extension of US copyright term, it did so in part on grounds that the Fair Use Doctrine provided the breathing room that a long copyright term required. Abolishing fair use in the US would therefore require extensive other, and compensating, changes in US law.

\section{ECONOMICS OF FAIR USE}

Almost all economic analyses of the economics of copyright protection argue that, to a greater or lesser degree, an optimal level of protection should leave some of the creative good unprotected. Even going back to the very origins of the literature on the economic rationale for copyright protection, the arguments were stacked more in favor of limiting protection than for strengthening it (see, for example, the seminal work of Plant, 1934, as well as the later work of Hurt and Schuchman, 1966, and Breyer, 1970). Thus, right from the very start the bases were in place for admitting that exceptions to full exclusionary power, of which we can understand fair use to be one, should be a general characteristic of an optimal copyright protection standard. An important point was added by Landes and Posner (1989), namely, that increasing the copyright protection to any one generation of authors increased the next generation's cost of creation.

In 1982, I proposed a market-failure approach to unifying the diverse fair use cases (Gordon, 1982). The article's immediate target was a judicial holding that would have disallowed fair use for exact, noncreative copying (such as home copying of television shows on a videocassette recorder, or library photocopying of copyrighted scientific research papers), and would have reserved fair use solely for creative adaptations ${ }^{17}$ (such as rewriting the lyrics of a copyrighted song for the purpose of mocking it in a parody). The larger goal of the article was to demonstrate that all fair use cases could be seen as judicial attempts to let parties achieve those social goals that a copyright owner and the affected user could not achieve through market trades. Such an approach made no necessary distinction between creative and non-creative copying.

Among other things, I argued that all fair use could be seen as a way to bypass the market when barriers such as high transaction costs or externalities made welfare-enhancing licenses impossible. Especially when copying 
would not have significant negative effects on incentives, and would have been agreed to by the copyright holder in absence of the transaction costs that create a barriers to negotiation, the copying should be allowed to take place. Such an access is part of what should be termed 'fair use', and it is founded on the idea that when market transactions for access to information are made impossible (or overly costly) to carry out, or when other forms of market failure make it unlikely that the market will facilitate transfers of copyright liberties to higher-valued users, courts should facilitate the liberty of use that would have been the result if perfect-market conditions were obtained.

This argument is especially strong when the desired dissemination or use of the authored work will not have severe adverse effects upon the welfare of the copyright owner or incentives for creativity. In such instances, fair use allows welfare-generating consumption to occur at no obvious cost to anyone, something that is clearly a Pareto dominating outcome. Since many copyright owners profit by indirect appropriability (Liebowitz, 1985) and sometimes price discrimination between single-use and multi-use customers can be profitable (Bakos, Brynjolfsson and Lichtman, 1999), lack of harm can often coexist with many kinds of free copying. In addition, fair use can be employed to allow welfare-generating consumption or creative use even when the use is costly so long as the costs are exceeded by the benefits to be generated; however, my article did not parse how these harder cases should be handled.

Back in 1982, transaction-cost barriers were probably the most obvious of the market failures that could justify fair use. For example, consider home videocassette copying of television shows (a use that the US Supreme Court in 1984 held was 'fair'). Television audiences had few if any contractual arrangements with content providers. Situation comedies, televised movies, variety shows, news programs, and the rest of TV's content traveled largely unscrambled over the airwaves; the typical home did not depend on a satellite descrambler or cable delivery system through which the home members' preferences for copying might otherwise have been monetized. And the selling of advertisement space - in 1982 the usual mode of capitalizing on a program's popularity - was of doubtful relevance to watchers who could copy and fast-forward past commercials. In such an environment, it was highly unlikely that any market could have determined the extent to which home copying might be cost-justified. Negotiations between potential home copiers and copyright-holder representatives were virtually impossible. In such a setting, one of the few ways through which socially valuable copying might proceed was via the fair use doctrine.

In the years following the videocassette copying case, transaction costs have reduced. The internet has flourished, and new contractual avenues for 
audience-supplier negotiation have opened not only through the internet but also through cable and satellite delivery of television. It was sometimes asked if fair use would vanish when transaction cost barriers reached zero.

The answer of course is that the need for fair use will remain strong, though its shape might change. Transaction-cost cases might reduce in frequency, but market failures still abound. Reductions in transaction costs will not empower users who cannot appropriate the benefits that their uses would generate: such actors, who generate positive externalities, are unable to purchase the licenses that their ability to serve the public would justify (Gordon, 1982, pp. 1607 and 1630-32, Loren, 1997, pp.48-53). Similarly, whatever happens to transaction costs, non-monetizable interests such as free speech will still require non-market accommodations such as fair use (Gordon 1982 and 2003); copyright owners who want to escape negative criticism will still refuse to license their critics 'at any price', leaving the critics in need of fair use (Gordon 1982 and 2003); people injured by copyrighted works will still need to copy the works to mount an effective self-defense (Gordon 1982 and 2003); and copyrighted works that function as expression in one context become non-copyrightable 'facts' in another, a shift in function that the fair use doctrine is uniquely equipped to recognize (Gordon, 1992). ${ }^{18}$

In addition, as some kinds of transaction costs declined, others have risen. Amendments to the US Copyright Act effective in 1989 eliminated the requirement for notice to be placed on copies of copyrighted work, and at an even earlier time registration with the Copyright Office became largely optional as well. This lack of 'formalities' makes it difficult to identify and locate copyright owners and thus creates difficulty in bargaining with them. Extensions of copyright duration intensify the problem, since the older a work is (ceteris paribus), the harder it is to find the people legally entitled to grant permissions. The number of so-called 'orphan works', whose authorial 'parentage' is unknown, has multiplied; such works have valid copyrights even though no one could negotiate for licenses to them, so that without fair use they could only be copied and creatively adapted at the users' peril. In all these cases, fair use might be the only way for socially desirable uses to occur lawfully.

In addition, as Depoorter and Parisi (2002) point out, many new works require the use of multiple prior copyrighted works, giving rise to an anticommons problem. An anti-commons is 'a property regime in which multiple owners hold effective rights of exclusion regarding a scarce resource'. Fair use is seen as an efficient way in which the so called 'tragedy of the anti-commons' can be avoided, in that if fair use is granted as a means of access, then welfare losses that occur from the strategic behavior of copyright holders can be minimized.

The type of situation that Depoorter and Parisi have in mind is when 
one creator would like to access parts of several existing copyright protected works in order to bring them together, along with entirely new elements, into a brand new work. Standard oligopoly price theory suggests that the total cost of securing each of the rights will exceed even the monopoly price if a single agent held all of the required copyrights, since effectively each individual copyright holder holds an essential input. The final outcome would be that the inputs (access to existing works) would be priced inefficiently high, and would therefore be underutilized. Allowing fair use, on the other hand, mitigates (or perhaps even eliminates) this inefficiency. Fair use may thus be an appropriate response to the need for multiple permissions otherwise faced by the 'Google Books' project.

In short, copyright creates markets to enable socially desirable uses of works of authorship. When the market requirement of permission and negotiation will not yield desirable results, US judges can use the flexible doctrine of fair use to legitimize the contested use despite the absence of the copyright owner's consent. There has also been some recent hints that judges may allow uses to go forward subject to a requirement of payment, using 'fair use' not to completely free the defendant from liability, but rather to free him or her from injunctive relief and statutory damages.

\section{CONCLUSIONS}

No one fully owns a book. The purchaser of the book owns a physical object - paper and glue and ink - over which his usual liberties of use are curtailed. He cannot fully use the patterns of words, notes or pictures in the book. Even the copyright owner lacks complete control over these patterns in the book. A wide range of unconsented uses are allowed. From private performance of the book's verbal or musical sequences, to building the machines depicted by the book's diagrams, or employing the systems the book teaches, even rewriting the book's basic entertainment ideas into a new expressive form - all of these copyright law permits. And unlike the ownership of tangible property, ownership of copyright shifts to the public after a stated duration expires.

No plausible economic argument could be made to defend a copyright law that lacked these or cognate limitations. All these limits are part of what make it socially tolerable and (potentially) efficient to have copyright's easy grant of exclusive rights for a lengthy term.

Among these many limits on copyright, fair use is distinctive for its case-by-case, standard-like form. It allows and encourages courts to engage in detailed consideration of particular circumstances. Given the importance of expression (copyright's province) to a democracy and to 


\section{Handbook on the economics of copyright}

any culture, a society investment of judicial resources into the particulars of copyright disputes is probably worthwhile. But we do not know this for sure. The available research largely recognizes the economic need for some limitations on copyright to exist; the inquiry now could well shift emphasis toward better identifying what package of limiting doctrines (and consequent public liberties) are optimal.

\section{NOTES}

1. Wendy J. Gordon is a William Fairfield Warren Distinguished Professor at Boston University, and Professor of Law at BU School of Law. She thanks Richard Watt for helpful assistance on this essay, and for supplying the appendix that appears after the end of the chapter.

2. To the extent other goals are met, some values will not be monetized. This will create a second-best problem for markets, that is, the presence of even one market imperfection can make inefficient moves to what seem like efficient points. Thus, regardless of what reductions in transaction costs result from technological and institutional breakthroughs, no perfect market is possible in any society that possesses goals other than efficiency. On problems of first-, second- and third-best economics, see for example, Markovits (2008).

3. See, for example, Kaplow (1992).

4. In addition to protecting the creative and original fixation of original patterns of words ('literary works') and musical notes ('musical works'), copyright also protects the creative and original fixation of many other categories of endeavor: audiovisual works; architectural works; pictorial, graphic and sculptural works; works composed of sounds; works of choreography; and so on. See 17 USC sec 102(a). For convenience of exposition, I will use word-patterns and music as examples standing in for the wider range of potentially copyrightable subject matters. Similarly, I will use the rights of reproduction and of public performance as examples to stand in for the wider range of rights that the law gives to copyright owners. See 17 USC sec 106.

5. Cf., Murphy (1980).

6. 17 USC 102(b).

7. See Merrill and Smith (2000).

8. If is far from clear, however, that the law's actual contours match public perceptions of how far copyright constrains physical-ownership rights. For some exploration of this divergence see, for example, Litman (1997).

9. Even sharp rules can have areas of vague or ambiguous application. (For example, consider the difficulty that 'on demand' services pose for the definition of 'public performance'. A slice of this issue was recently decided by the US Supreme Court American Broadcasting Companies, Inc. v. Aero, Inc., _U.S._, 134 S.Ct. 2498 (June 25, 2014).) But once a question of rule is addressed by an authoritative court, the sharpness returns and the newly announced rule is enforced. By contrast, standards like 'fair use' usually remain open for case-by-case reconsideration. For example, when a respected federal appeals court attempted to resolve 'fair use' cases by applying a presumption that commercial uses were 'unfair', the U S Supreme Court rejected the attempt in favor of emphasizing the way the factors of the fair use doctrine 'will vary with the context', Campbell v. Acuff-Rose Music, 510 U.S. 569 at 586 (1994), reiterating that 'Congress had "eschewed a rigid, bright-line approach to fair use"...' Id. at 584 (quoting its prior opinion in Harper \& Row, Publishers, Inc. v. Nation Enterprises, 471 U.S. 539 (1985).)

10. 17 USC 106(2); also see sec. 103. 
11. Sony Corp. of America v. Universal City Studios, 464 US 417 (1984), reversing 652 F 2d 953 (1981).

12. Other features of the case may have played a role as well, such as a judicial reluctance to regulate largely harmless behavior in the home.

13. See Kitch (1999).

14. 17 USC 107, accessed 16 April 2014 at http://www.copyright.gov/title17/circ92.pdf.

15. See, for example, Samuelson (2009).

16. See, for example, Bongiorno (2009).

17. Today fair use doctrine gives particularly generous treatment to 'transformative' uses, but judges have stretched the word 'transformative' to include exact copies so long as a new purpose case be discerned.

18. Congress seems to have concluded, with reason, that facts and ideas are most likely to be efficiently used when the entitlement to use them is distributed widely as a liberty, rather than concentrated in one owner as an exclusive right. See 17 USC 102(b) (no copyright in ideas and discoveries). Yet some objects function both as expressive works and as facts. Fair use can be used to identify on a case-by-case basis the occasions when a work that usually functions as expression is instead functioning as a fact, that is, fair use inquiry can identify the occasional cases where a creative work's evidentiary function trumps the expressive. For example, in Nuñez v. Caribbean Int'l News Corp., 235 F.3d 18 (1st Cir. 2000), a newspaper reprinted a copyrighted photograph, without permission, as a fact for the public to view as an aid for judgment about a current controversy. Although the photo ordinarily functioned as expression, here it functioned instead as evidence. The court accordingly gave the newspaper the shelter of the fair use doctrine. Without fair use, and given the public's inability to organize itself for purchase, the entitlement to use the copyrighted photo would not have switched back to the public.

\section{REFERENCES}

Bakos, Y., E. Brynjolfsson and D. Lichtman (1999), 'Shared information goods', The Journal of Law \& Economics, 42 (1), 117-56.

Bongiorno, J. (2009), 'Fair use of copyrighted images after Perfect 10 v. Amazon.com: diverging from constitutional principles \& United States treaty obligations', Touro International Law Review, 12, 107-56.

Boyer, M. (2012), 'The economics of fair use/dealing: copyright protection in a fair and efficient way', Review of Economic Research on Copyright Issues, 9 (1), 3-46.

Breyer, S. (1970), 'The uneasy case for copyright: a study of copyright in books, photocopies, and computer programs', Harvard Law Review, 84, 281-351.

Calabresi, G. (1961), 'Some thoughts on risk distribution and the law of torts', Yale Law Journal, 70, 499-553.

Coase, R.H. (1960), 'The problem of social cost', Journal of Law and Economics, 3, 1-44.

Depoorter, B. and F. Parisi (2002), 'Fair use and copyright protection: a price theory explanation', International Review of Law and Economics, 21, 453-73.

Gordon, W. (1982), 'Fair use as market failure: a structural and economic analysis of the Betamax case and its predecessors', Columbia Law Review, 82, 1600-657.

Gordon, W. (1992), 'Reality as artifact: from Feist to fair use', Law and Contemporary Problems, 55 (2), 93-107.

Gordon, W. (2003), 'Excuse and justification in the law of fair use: transaction costs have always been only part of the story', Journal of the Copyright Society of the USA, 13, 149-97.

Hurt, R. and R. Schuchman (1966), 'The economic rationale of copyright', American Economic Review, 56 (2), 421-32.

Kaplow, L. (1992), 'Rules versus standards: an economic analysis', Duke Law Journal, 42, $557-629$. 


\section{Handbook on the economics of copyright}

Kitch, E.W. (1999), 'Can the Internet shrink fair use?', Nebraska Law Review, 78, 880-90.

Klein, B., A. Lerner and K. Murphy (2002), "The economics of copyright and "fair use" in a networked world', American Economic Review, 92, 205-8.

Koboldt, C. (1995), 'Intellectual property and optimal copyright protection', Journal of Cultural Economics, 19, 131-55.

Landes, W. and R. Posner (1989), 'An economic analysis of copyright law', Journal of Legal Studies, 18, 325-63.

Landes, W. and R. Posner (2003), The Economic Structure of Intellectual Property Law, Cambridge, MA and London, UK: Harvard University Press.

Liebowitz, S. (1985), 'Copying and indirect appropriability: photocopying journals', Journal of Political Economy, 93 (5), 945-57.

Litman, J. (1997), 'Reforming information law in copyright's image', University of Dayton Law Review, 22 (3), 588-619.

Loren, L.P. (1997), 'Redefining the market failure approach to fair use in an era of copyright permission systems', Journal of Intellectual Property Law, 5 (1), 1-58.

Markovits, R.S. (2008), Truth or Economics: On the Definition, Prediction, and Relevance of Economic Efficiency, New Haven, CT: Yale University Press.

Merrill, T.W. and H.E. Smith (2000), 'Optimal standardization in the law of property: the Numerus Clausus principle', Yale Law Journal, 110, 1-70.

Miceli, T. and R. Adelstein (2006), 'An economic model of fair use', Information Economics and Policy, 18, 359-73.

Murphy, J.G. (1980), 'Blackmail: a preliminary inquiry', The Monist, 63 (2), 156-171, accessed 16 April 2014 at http://www.jstor.org/stable/27902635.

Novos, I. and M. Waldman (1984), 'The effects of increased copyright protection: an analytic approach', Journal of Political Economy, 92, 236-46.

Plant, A. (1934), 'The economic aspects of copyright in books', Economica, 48, 167-95.

Pollock, R. (2007), 'Optimal copyright over time: technological change and the stock of works', Review of Economic Research on Copyright Issues, 4 (2), 51 - 64.

Samuelson, P. (2009), 'Unbundling fair uses', Fordham Law Review, 77 (5), 2537-621. 